\title{
Optimization of Operation Conditions for Improving the Nitrogen Removal Efficiency in Wastewater Treatment Plant
}

\author{
질소제거효율 향상을 위한 하수처리장 최적 운전조건 도출 연구 \\ Choi, Eun-Hee ${ }^{*,+} \cdot$ Bram Klapwijk** Mathijs Oosterhuis ${ }^{* * *}$ \\ 최은희,+ · 브람 클라벡** 마타이 오스터하우스 ${ }^{* * *}$
}

\begin{abstract}
네덜란드 브리젠빈 하폐수처리장 최종방류수의 $\mathrm{NH}_{4}-\mathrm{N}$ 및 $\mathrm{TN}$ (Total Nitrogen)농도를 방류수 수질기준인 각각 $4 \mathrm{mg} / \mathrm{L}$ 와 10 $\mathrm{mg} / \mathrm{L}$ 에 맞추기 위한 최적의 운전조건을 도출하기 위해 다양한 제어시스템이 시뮬레이션 되었다. 본 연구에 사용된 모델은 IWA (International Water Association) 활성슬러지 모델 No.1 (ASM No.1)이었고, GPS-X가 시뮬레이터로 사용되었다. 모델링을 위한 매 개변수 민감도 분석결과 ASM No.1의 총 19개 매개변수 중 8개 변수 $\left(\mathrm{Y}_{\mathrm{H}}, \mathrm{ksh}, \mathrm{koh}, \mathrm{b}_{\mathrm{H}}, \mu_{a}, \mathrm{k}_{\mathrm{NA}}, \mathrm{kh}, \mathrm{ka}\right)$ 가 방류수 수질에 영향을 미치는 것으로 조사되었고 이들 매개변수에 대해 보정을 수행하여 사용하였다. SRT, 호기/무산소기간, 외부탄소원 주입시간 변화 에 따른 방류수질 변화를 시뮬레이션하였는데, 호기/무산소 $11 \mathrm{~h} / 1 \mathrm{~h}$ 인 조건에서 SRT가 20일에서 25일로 증가되면 $\mathrm{NH}_{4}-\mathrm{N}$ 가 5.0 $\mathrm{mg} / \mathrm{L}$ 에서 $2.9 \mathrm{mg} / \mathrm{L}$ 로 감소되었고 호기/무산소 $2 \mathrm{~h} / 1 \mathrm{~h}$ 의 조건에서는 $\mathrm{SRT}$ 증가에 따라 $\mathrm{NH}_{4}-\mathrm{N}$ 은 큰 감소를 보이지만, 바이패스되는 유입수량의 감소로 탈질율이 낮아 방류수 TN이 $11.1 ~ 11.5 \mathrm{mg} / \mathrm{L}$ 로 예측되는 결과가 도출되었다. 탈질율을 높이기 위한 아세트산 주입은 동일한 양의 아세트산을 무산소 전기간 $(1 \mathrm{~h})$ 동안 균일 주입하는 것 보다는 무산소 초기 15 분내에 주입하는 것이 효율적 인 것으로 나타났다.
\end{abstract}

Keywords: N-removal, Oxidation ditch, ASM no.1, GPS-X, Parameter estimation, Simulation

\section{NOMENCLATURE}

$b_{\mathrm{H}}=$ Heterotrophic decay rate $(1 / \mathrm{d})$

$\mathrm{k}_{\mathrm{a}}=$ Ammonification rate $\left(\mathrm{m}^{3} / \mathrm{g} \mathrm{COD} / \mathrm{d}\right)$

$\mathrm{k}_{\mathrm{h}}=$ maximum specific hydrolysis rate $(1 / \mathrm{d})$

$\mathrm{k}_{\mathrm{NA}}=$ Ammonia half saturation coefficient for autotrophs growth $\left(\mathrm{g} \mathrm{N} / \mathrm{m}^{3}\right)$

$\mathrm{k}_{\mathrm{oh}}=$ Oxygen half saturation coefficient $\left(\mathrm{g} \mathrm{O}_{2} / \mathrm{m}^{3}\right)$

$\mathrm{Y}_{\mathrm{H}}=$ Heterotrophic yield coefficient $(\mathrm{g}$ COD/g COD)

$k_{\text {sh }}=$ Readily biological substrate half saturation coefficient $\left(\mathrm{g} \mathrm{COD} / \mathrm{m}^{3}\right)$

$\mu_{a}=$ Autotrophic maximum specific growth rate $(1 / \mathrm{d})$

$\mu_{H}=$ Heterotrophic maximum specific growth rate $(1 / \mathrm{d})$

* 한국농어촌공사 농어촌연구원

** Wageningen University, The Netherlands

*** Waterschap Regge en Dinkel, The Netherlands,

† Corresponding author. Tel.: +82-31-400-1803

Fax: +82-31-400-1889

E-mail address: ehchoi@ekr.or.kr

2009년 11월 6일 투고

2010년 1월 7일 심사완료

2010년 1월 13일 게재확정

\section{INTRODUCTION}

The communal wastewater treatment plant (WWTP) of Vriezenveen, the Netherlands consists of two trickling filters followed by an oxidation ditch. The oxidation ditch is operated by intermittent aeration to achieve Nremoval based on alternating nitrification and denitrification. There is insufficient organic carbon (BOD) available for denitrification as most of the BOD is removed in the trickling filters.

One of the solution for carbon supply is that a certain amount of influent to the primary settler is bypassed directly to the oxidation ditch during the anoxic period.

Two control methods are applied for the aerobic/anoxic cycle time, i.e. set point control based on nitrate concentration (summer season) and fixed time control (winter season) for offering longer nitrification time in winter. However the WWTP of Vriezenveen has still a low nitrification rate in winter season and the denitrification rate is low too. As a result, the N-removal of the 
plant is too low during the winter. Therefore an external carbon source (acetic acid) is added during the winter season, but the required $\mathrm{N}-$ removal $\left(\mathrm{NH}_{4}-\mathrm{N}<4 \mathrm{mg} \mathrm{N} / \mathrm{L}\right.$, $\mathrm{TN}<10 \mathrm{mg} \mathrm{N} / \mathrm{L}$ ) is not obtained.

The aim of this study was to find out an appropriate operation method which one resulted in the lowest nitrogen concentration in the effluent. Model calibration and validation have been carried out for the WWTP of Vriezenveen and then the effect of each operation method was examined in higher SRT(Sludge Retention Time), different aerobic/anoxic cycle times, dosing time.

In this study, the system was simulated using Activated Sludge Model No. 1 (ASM1). ASM No.1 proposed by the International Water Association (IWA) task group on Mathematical Modeling for Design and Operation of Biological Wastewater Treatment are the most commonly applied mathematical models for the modelling of the biological compartments of wastewater treatment plants. The ASMs have been successfully applied to full-scale treatment plants and shown to be a good compromise between the complexity of the activated sludge processes and reduction of the plant behavior under dynamic conditions.

GPS-X (Hydromantis, 1999), developed by using a mechanistic approach which combines the robust IWA ASMs, is a modular, multi-purpose modeling environment for the simulation of municipal and industrial wastewater treatment plants. In this study GPS-X was used as a simulator.

\section{MATERIALS AND METHODS}

\section{Description of Vriezenveen wastewater treatment plant}

The WWTP of Vriezenveen consists of two main biological processes; biological conversion in a trickling filter and the activated sludge process in an oxidation ditch. Wastewater first passes a primary clarifier and then a trickling filter where most of carbonaceous matter (BOD) is removed. The next step is nitrogen removal by nitrification and denitrification in the oxidation ditch. The oxidation ditch (volume $1,700 \mathrm{~m}^{3}$ ) is equipped with an on-line $\mathrm{DO}$ and $\mathrm{NO}_{3}-\mathrm{N}$ analyzer and is operated at an
SRT of 20 days treating an average flowrate of 4,300 $\mathrm{m}^{3} / \mathrm{d}$. The flow velocity in the ditch is $0.2-0.3 \mathrm{~m} / \mathrm{s}$. The oxygen concentration maintained at $1.5 \mathrm{mg} / \mathrm{L}$ of DO. The aerobic/anoxic cycle time was controlled by time setting during the winter and during the summer, set point control was achieved based on nitrate concentration (4-8 $\mathrm{mg} / \mathrm{L} \mathrm{NO}_{3}-\mathrm{N}$ ). External carbon source (acetic acid, $85 \%$ ) as denitrification supporter during the anoxic period is only added in the winter period. The average temperature is $10{ }^{\circ} \mathrm{C}$ (in winter) and $17{ }^{\circ} \mathrm{C}$ (in summer).

\section{Model calibration}

Model calibration was carried out with the following steps: sensitivity test, parameter estimation and validation. A GPS-X simulator was used for calibration and simulation. The activated sludge model No. 1(Henze, et al, 1986) was used for the oxidation ditch and the simple $1 \mathrm{~d}$ model (Horner et al, 1986) was used for the 2nd clarifier. Wastewater characterization was performed according to the STOWA-method (Roeleveld and Loosdrecht, 2002). The data of 2002-2003 was used for calibration of the model.

The model (Fig. 1) consisted of two influent streams (trickling filter effluent and influent of the primary settler as a bypass flow), an oxidation ditch by a loop of six equal CSTR(Continuous Stirred-Tank Reactor)'s and a secondary clarifier. The trickling filter effluent was modelled as a continuous stream and the bypass flow as a discontinuous stream (only during the anoxic period).

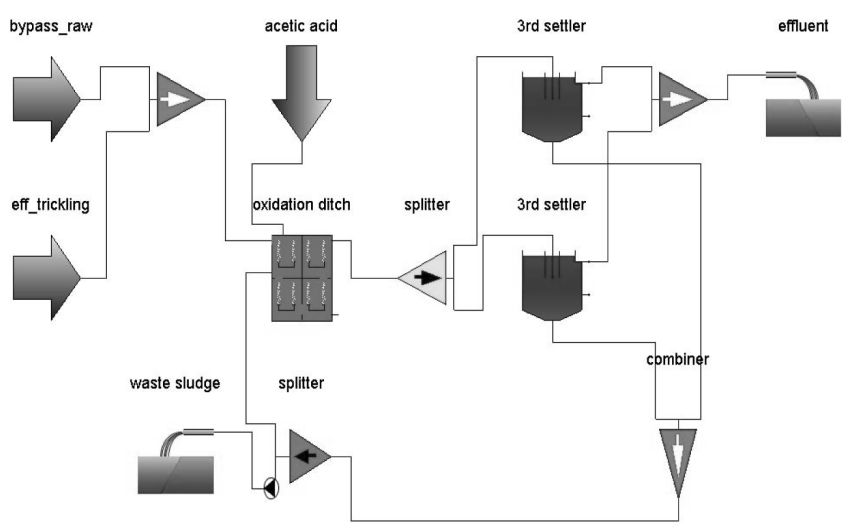

Fig. 1 Layout of Vriezenveen WWTP focused on the oxidation ditch 


\section{A. Sensitivity Test}

The sensitivity test was conducted based on the performance assessment, developed for benchmarking of activated sludge systems by the COST 624 working group (Pons et al, 1999) and the IWA Task group on respirometry (Copp, 2000). Performance assessment for benchmarking consists of four sub-levels: effluent quality (EQ), pumping energy (PE), aeration energy (AE) and total sludge production (TSP). Except EQ, all levels are related to cost-factors for operation. In this work only the EQ-index was used in order to detect the main effects of the parameters on the effluent quality. All the parameters were in turn varied around their default value, while the others remained fixed.

The effluent quality index (EQ) ( $\mathrm{kg}$ pollution /d) is defined as:

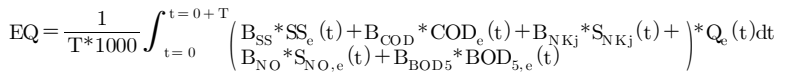

$$
\begin{aligned}
& \mathrm{S}_{\mathrm{NKj, \textrm {e }}}=\mathrm{S}_{\mathrm{NH}, \mathrm{e}}+\mathrm{S}_{\mathrm{ND}, \mathrm{e}}+\mathrm{X}_{\mathrm{ND}, \mathrm{e}}+\mathrm{i}_{\mathrm{XB}}\left(\mathrm{X}_{\mathrm{BH}, \mathrm{e}}+\mathrm{X}_{\mathrm{BA}, \mathrm{e}}\right) \\
& +\mathrm{i}_{\mathrm{XP}}\left(\mathrm{X}_{\mathrm{P}, \mathrm{e}}+\mathrm{X}_{\mathrm{i}, \mathrm{e}}\right) \\
& \mathrm{SS}_{\mathrm{e}}=0.75\left(\mathrm{X}_{\mathrm{S}, \mathrm{e}}+\mathrm{X}_{\mathrm{I}, \mathrm{e}}+\mathrm{X}_{\mathrm{BH}, \mathrm{e}}+\mathrm{X}_{\mathrm{BA}, \mathrm{e}}+\mathrm{X}_{\mathrm{P}, \mathrm{e}}\right) \\
& \mathrm{BOD}_{5, \mathrm{e}}=0.25\left(\mathrm{~S}_{\mathrm{S}, \mathrm{e}}+\mathrm{X}_{\mathrm{S}, \mathrm{e}}+\left(1-\mathrm{f}_{\mathrm{p}}\right) \cdot\left(\mathrm{X}_{\mathrm{BH}, \mathrm{e}}+\mathrm{X}_{\mathrm{BA}, \mathrm{e}}\right)\right) \\
& \mathrm{COD}_{\mathrm{e}}=\mathrm{S}_{\mathrm{S}, \mathrm{e}}+\mathrm{S}_{\mathrm{I}, \mathrm{e}}+\mathrm{X}_{\mathrm{S}, \mathrm{e}}+\mathrm{X}_{\mathrm{I}, \mathrm{e}}+\mathrm{X}_{\mathrm{BH}, \mathrm{e}}+\mathrm{X}_{\mathrm{BA}, \mathrm{e}}+\mathrm{X}_{\mathrm{P}, \mathrm{e}}
\end{aligned}
$$

The $\mathrm{B}_{\mathrm{SS}} \sim \mathrm{B}_{\mathrm{BOD} 5}$ are weighting factors for the different types of pollution to convert them into pollution units (Table 1). The weighting factors have been deduced from Vanrolleghem et al. (1996).

Table 1 Weighting factors for the different types of pollution to convert them into pollution units

\begin{tabular}{c|c|c|c|c|c}
\hline Factor & $\mathrm{B}_{\mathrm{SS}}$ & $\mathrm{B}_{\mathrm{COD}}$ & $\mathrm{B}_{\mathrm{NKj}}$ & $\mathrm{B}_{\mathrm{NO}}$ & $\mathrm{B}_{\mathrm{BOD} 5}$ \\
\hline \hline Value(g pollution/g) & 2 & 1 & 20 & 20 & 1 \\
\hline
\end{tabular}

\section{B. Parameter Estimation and Validation}

Based on the results of the sensitivity tests, 8 model parameters: $\left(\mathrm{Y}_{\mathrm{H}}, \mathrm{ksh}, \mathrm{koh}, \mathrm{b}_{\mathrm{H}}, \mu_{a}\right.$, kna, kh and ka) were selected for parameter estimation, for the other model parameters ASM No.1 default values (Henze, et al, 1986) were used. Input/output and operational data of 2003 summer (May to September) and 2003 winter (October to December) were used to estimate the parameters of each period. Measured variables were temperature (mean value of summer and winter: 17 and $10{ }^{\circ} \mathrm{C}$ ), MLSS/MLVSS (Mixed Liquor (Volatile) Suspended Solids) in the oxidation ditch, flowrate, $\mathrm{BOD}_{5}, \mathrm{COD}$ tot, TKN, $\mathrm{NH}_{4}-\mathrm{N}$ of influent/ effluent, and effluent $\mathrm{SS}, \mathrm{NO}_{3}-\mathrm{N}$. The estimation procedure was carried out with the optimiser module of GPS-X. The data of January 2002 - April 2003 (BOD, COD, TKN, $\mathrm{TN}, \mathrm{NH}_{4}-\mathrm{N}, \mathrm{NO}_{3}-\mathrm{N}$, SS and MLSS) were used for validation.

\section{SIMULATIONS}

The simulations were focused on the effects of the SRT, aerobic/anoxic time and acetic acid dosing on the effluent nitrogen concentration. The SRT was varied between 20 and 30 days by controlling the flowrate of waste sludge. The defined aerobic/anoxic cycle times were $1 \mathrm{~h} / \mathrm{h}$ and $2 \mathrm{~h} / \mathrm{h}$.

In practice, acetic acid (about $19 \mathrm{~kg}$ COD/cycle) is added to the oxidation ditch in 30 minutes time during the anoxic period. In this simulation, the same amount of acetic acid was added during the anoxic period (aerobic $2 \mathrm{~h}$ /anoxic $1 \mathrm{~h}$ ) with dosing times of $15 \mathrm{~min}, 30 \mathrm{~min}$ and $60 \mathrm{~min}$. In the cases of 15 and $30 \mathrm{~min}$, the anoxic period was still $60 \mathrm{~min}$. The temperature in the oxidation ditch was $10{ }^{\circ} \mathrm{C}$ in winter and $20{ }^{\circ} \mathrm{C}$ in summer.

\section{RESULTS AND DISCUSSIONS}

\section{Vriezenveen WWTP}

The treatment plant was first constructed to remove only organic matter (trickling filter process) and later extended for nitrogen removal. The TKN concentration of the wastewater was $61 \mathrm{mg} \mathrm{N} / \mathrm{L}$ and BOD $253 \mathrm{mg} / \mathrm{L}$ (2002-2003 average) resulting in a BOD/TKN ratio of 4.1. However, the primary clarifier and the trickling filters removed most of the BOD. The overflow of the trickling filters only contains $35 \mathrm{mg} / \mathrm{L}$ of $\mathrm{BOD}$ and 25 mg TKN/L $(B O D / N=1.4)$. For supplementing extra BOD, 
Table 2 Results of parameter estimation

\begin{tabular}{|c|c|c|c|c|c|c|c|c|c|}
\hline \multicolumn{2}{|c|}{ Parameter } & $\mathrm{Y}_{\mathrm{H}}$ & ksh & koh & $\mathrm{b}_{\mathrm{H}}$ & $\mu_{a}$ & $\mathrm{k}_{\mathrm{NA}}$ & kh & ka \\
\hline \multicolumn{2}{|c|}{ Unit } & 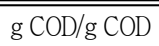 & $\mathrm{g} \mathrm{COD} / \mathrm{m}^{3}$ & $\mathrm{~g} \mathrm{O}_{2} / \mathrm{m}^{3}$ & $1 / \mathrm{d}$ & $1 / \mathrm{d}$ & $\mathrm{g} \mathrm{N} / \mathrm{m}_{3}$ & $1 / \mathrm{d}$ & $\mathrm{m}^{3} / \mathrm{g} \mathrm{COD} / \mathrm{d}$ \\
\hline \multicolumn{2}{|c|}{ Default value } & 0.67 & 20 & 0.2 & 0.62 & 0.8 & 1 & 3 & 0.08 \\
\hline \multirow{2}{*}{ Estimated value } & summer & 0.66 & 20.7 & 0.4 & 0.64 & 0.9 & 0.9 & 3 & 0.07 \\
\hline & winter & 0.66 & 27.5 & 0.1 & 0.62 & 0.33 & 0.8 & 2.6 & 0.03 \\
\hline
\end{tabular}

influent of the primary settler was bypassed directly to the oxidation ditch in the anoxic period and in winter also external carbon source was added (85\% acetic acid, $19 \mathrm{~kg} \mathrm{COD/cycle).}$

\section{Model calibration}

\section{A. Sensitivity test}

Fig. 2 shows the results of the sensitivity tests. This figure presents the standard deviation of $\mathrm{EQ}$ index relative to the ASM No. 1 default values for 16 different model parameters. The EQ index is significantly sensitive to only eight parameters: $\mathrm{Y}_{\mathrm{H}}$, ksh, koh, $\mathrm{b}_{\mathrm{H}}, \mu_{a}, \mathrm{k}_{\mathrm{NA}}$, kh, and ka and among these, ksh, $\mu_{a}, b_{H}$ and kh are revealed as the most sensitive to the EQ index. Even $\mu_{h}$ is known as a significant parameter for COD removal (Abusam et al, 2001), but due to weighting factors which were adopted in the $\mathrm{EQ}$ index equation to focus on nitrogen removal, it has less sensitivity to the $\mathrm{EQ}$ index.

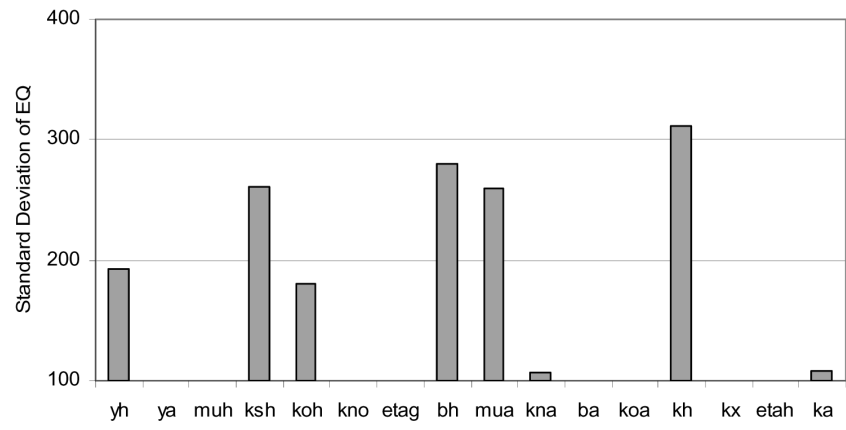

Fig. 2 Standard deviation of EQ index relative to the ASM No. 1 default value.

\section{B. Parameter estimation}

Table 2 presents the results of the parameter estimation and most of parameters have almost the same value as the default values of ASM No. 1 except $\mu_{a}$ and ka which are connected with nitrifier's growth and ammonification rate, respectively. Discrepancy of these value can explain why nitrification rate is lower and as a results the effluent $\mathrm{NH}_{4}-\mathrm{N}$ concentration is higher in winter.

\section{Validation}

In Fig. 3, the simulation results over one and half year are plotted together with the real data set. The simulation results shows similar tendency of observed data, however during early 2003, the plant was operated with unusual aerobic/anoxic times and this explains the small discrepancy for TN during that period.

\section{Simulation}

\section{A. Effects of the SRT and aerobic/anoxic time}

Simulations at winter conditions (time controlled; addition of acetic acid) are presented in Table 3. At an SRT of 20 days and an aerobic/anoxic time of $1 \mathrm{~h} / 1 \mathrm{~h}$, the effluent $\mathrm{NH}_{4}-\mathrm{N}$ and $\mathrm{TN}$ are $5.0 \mathrm{mg} \mathrm{N} / \mathrm{L}$ and $10.3 \mathrm{mg} \mathrm{N} / \mathrm{L}$ respectively, thus higher than the required 4.0 and $10 \mathrm{mg} \mathrm{N} / \mathrm{L}$. Increasing the aerobic time $(2 \mathrm{~h} / \mathrm{h} \mathrm{h})$ results in a decrease of $\mathrm{NH}_{4}-\mathrm{N}$ but $\mathrm{NO}_{3}-\mathrm{N}$ increases, because less wastewater is bypassed in anoxic period. Increasing the SRT from 20 to 25 and to 30 days (aerobic/anoxic time $2 \mathrm{~h} / 1 \mathrm{~h}$ ) has almost no effect on the $\mathrm{NH}_{4}-\mathrm{N}$ and $\mathrm{NO}_{3}-\mathrm{N}$ concentrations. Increasing the SRT to 25 days and then 30 days (1h aerobic/1h anoxic) results in a decrease in $\mathrm{NH}_{4}-\mathrm{N}$ and smaller increase in $\mathrm{NO}_{3}-\mathrm{N}$ compared with a SRT of 20 days. The concentration of nitrifiers is increased resulting in a higher nitrification rate and more nitrate production, but as a result of relatively insufficient substrate not all the extra nitrate is removed, resulting in an increase of the nitrate concentration; the sum of $\mathrm{NH}_{4}-\mathrm{N}$ and $\mathrm{NO}_{3}-\mathrm{N}$ decreases gradually. Increasing the SRT improves thus the $\mathrm{NH}_{4}-\mathrm{N}$ and $\mathrm{TN}$ and they are below the limits of 4 and $10 \mathrm{mg} \mathrm{N} / \mathrm{L}$ respectively. 
BOD

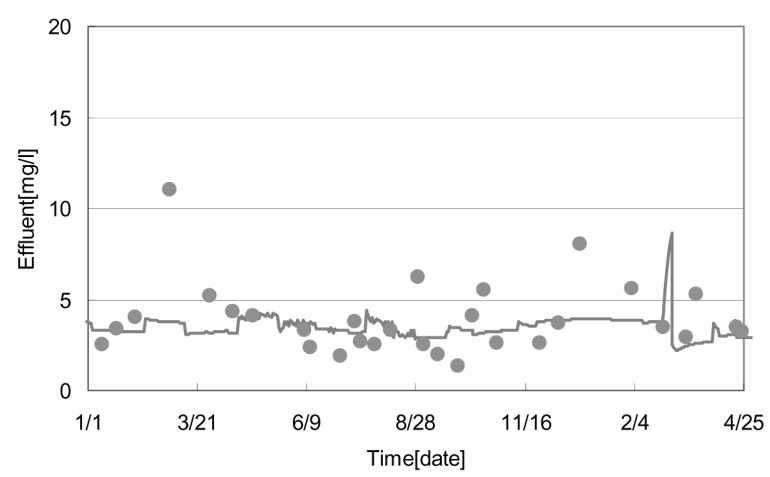

TN

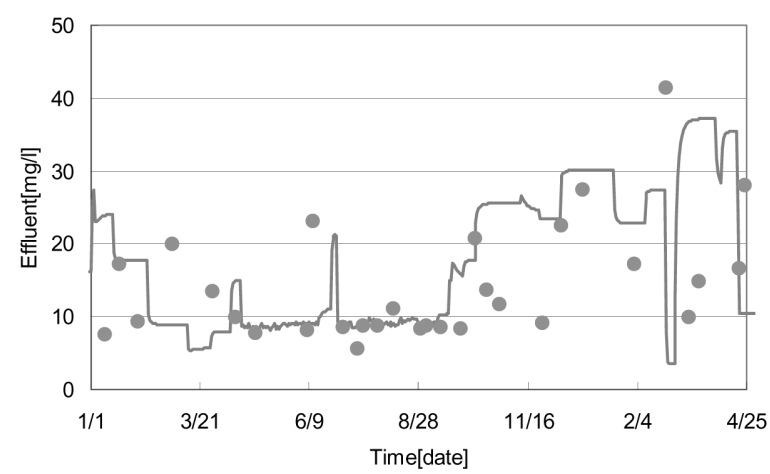

COD

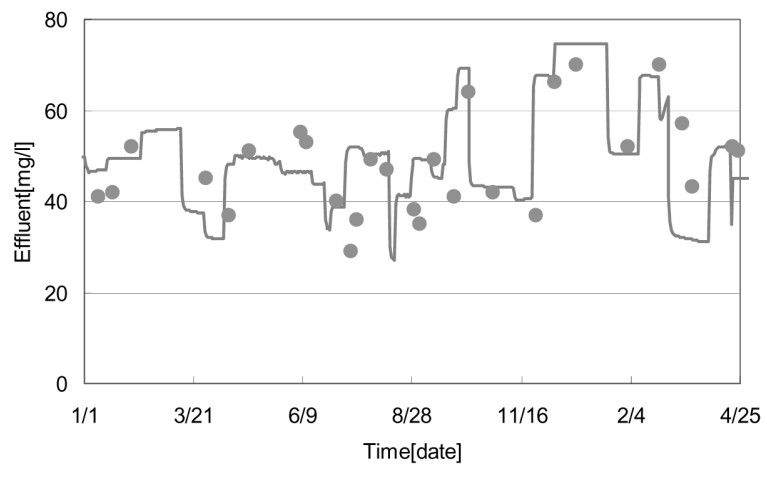

MLSS

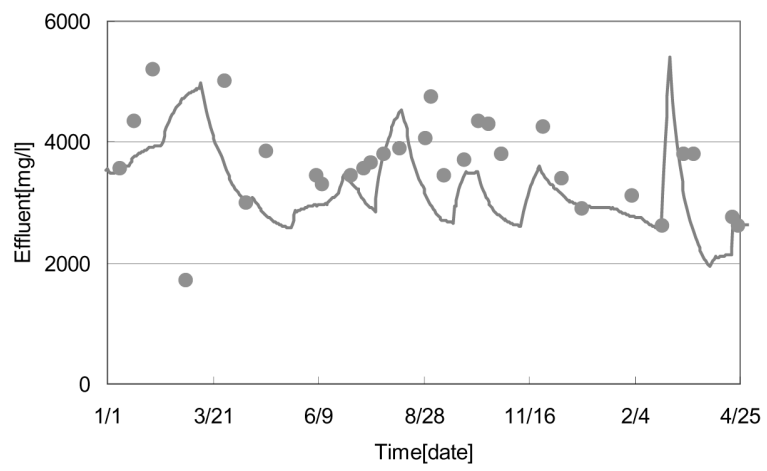

Fig. 3 Results of model validation: dot-observed, line-simulated

Table 3 The effect of changing SRT and aerobic/anoxic cycle time to effluent nitrogen concentrations

\begin{tabular}{c|c|c|c|c|c|c}
\hline Time controlled & \multicolumn{3}{|c|}{ Aerobic/anoxic=1h/1h } & \multicolumn{3}{c}{ Aerobic/anoxic=2h/1h } \\
\hline SRT & 20 days & 25 days & 30 days & 20 days & 25 days & 30 days \\
\hline \hline $\begin{array}{c}\text { Effluent BOD } \\
(\mathrm{mg} / \mathrm{L})\end{array}$ & 3.8 & 3.6 & 3.7 & 3.6 & 3.5 & 3.4 \\
\hline $\begin{array}{c}\text { Effluent NH} \\
(\mathrm{mg} \mathrm{N} / \mathrm{L})\end{array}$ & 5.0 & 2.9 & 2.5 & 1.5 & 1.3 & 1.2 \\
\hline $\begin{array}{c}\text { Effluent NO } \\
\text { (mg N/L) }\end{array}$ & 3.7 & 4.5 & 4.6 & 8.4 & 8.3 & 8.2 \\
\hline $\begin{array}{c}\text { Effluent TN } \\
(\mathrm{mg} \mathrm{N} / \mathrm{L})\end{array}$ & 10.3 & 9.2 & 8.9 & 11.5 & 11.2 & 11.1 \\
\hline
\end{tabular}

\section{B. Effect of dosing time}

Acetic acid is in general added during the first 30 minutes of the anoxic period. The effect of the acetic acid dosing time was simulated (Fig. 4). The same amount of acetic acid (19 kg COD/cycle, aerobic 2h/anoxic 1h) was added to the oxidation ditch but in different dosing times: 15, 30 and 60 min. Decreasing the dosing time results in decrease of effluent $\mathrm{NO}_{3}-\mathrm{N}$ to $0.5 \mathrm{mg} \mathrm{N} / \mathrm{L}$ and

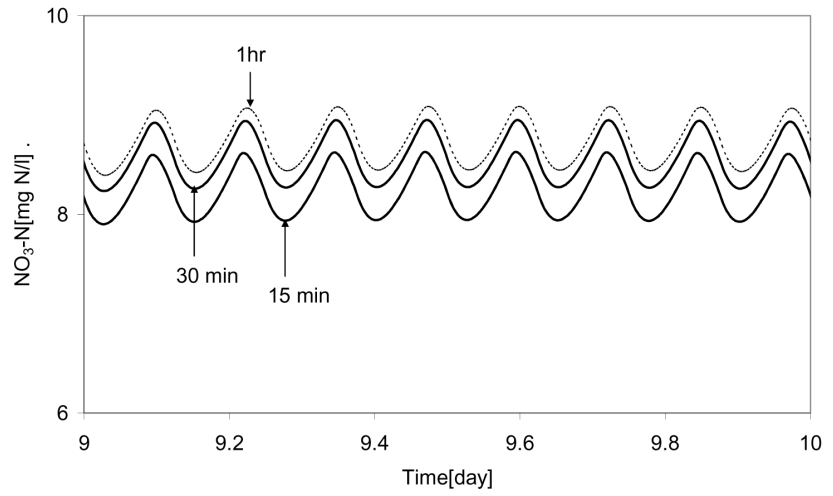

Fig. 4 The effect of acetic acid dosing time on $\mathrm{NO}_{3}-\mathrm{N}$ in the effluent

$0.6 \mathrm{mg} \mathrm{N} / \mathrm{L}$, respectively.

Fig. 5 shows the effect of the dosing time on the denitrification rate (DNR). The DNR increases immediately when acetic acid is added and decreases sharply at the end of the dosing period except in case of dosing time 1hr. By shortening the dosing time the DNR increased from 2.9 to $6.8 \mathrm{mg}$ N/L.h. The observed DNR in the plant, 


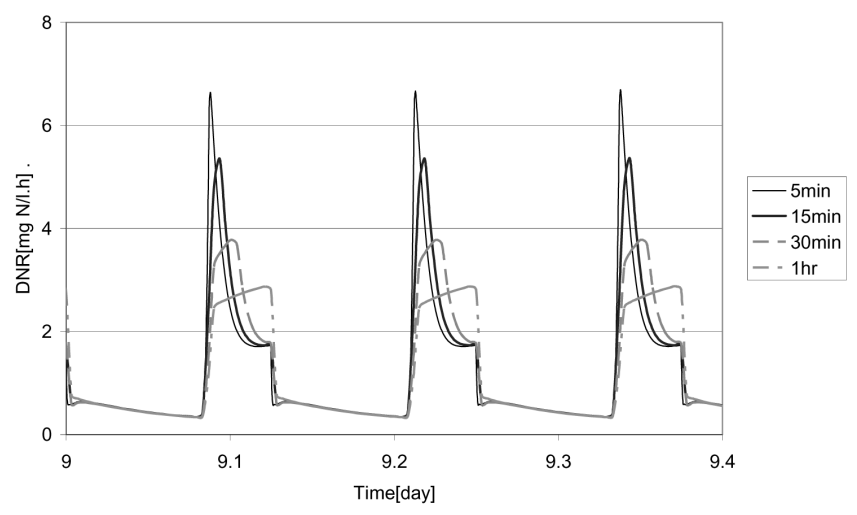

Fig. 5 The effect of acetic acid dosing time on DNR.

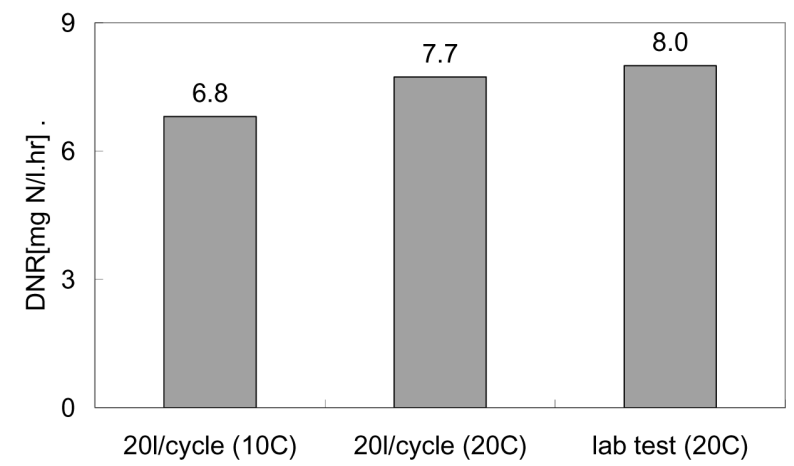

Fig. 6 Comparison of simulated DNR and DNR from a lab test

in case of no acetic acid dosage but bypass of influent of the primary settler is $1.8 \mathrm{mg} \mathrm{N} / \mathrm{L} . \mathrm{h}$ and it can explain that in this plant, lower dinitrification rate are derived from less organic carbon.

The DNR of the simulation was validated with a lab test at a temperature of $20{ }^{\circ} \mathrm{C}$ (Fig. 6). The acetic acid was added at the start of the test to measure the maximum DNR. The result of this test was almost the same as the DNR with $5 \mathrm{~min}$ dosing time at $20{ }^{\circ} \mathrm{C}$. The DNR in the simulation at $10{ }^{\circ} \mathrm{C}$ is of course lower. The result of the lab test confirms that the simulation results represent the plant situation quite well.

\section{CONCLUSIONS}

The WWTP of Vriezenveen (intermittent aeration in an oxidation ditch) was modelled in three steps. 1) Based on the sensitivity test the model parameters $Y_{H}$, ksh, koh, $b_{H}, \mu_{a}, k_{\mathrm{NA}}$, kh and ka are mainly determining the effluent quality. 2) Parameter estimation with 2003-summer and winter data resulted for these parameters in values that were almost the same as the ASM No. 1 default values except $\mu_{a}$ and ka 3) The simulation results fitted with the 2002-2003 data.

Three control systems to improve N-removal were simulated, 1) Increasing the SRT 2) Increase of the aerobic time 3) Decreasing of the acetic acid dosing time and increasing dosage.

Increasing the SRT (aerobic/anoxic: $1 \mathrm{~h} / \mathrm{lh}$ ) results in a lower $\mathrm{NH}_{4}-\mathrm{N}$ and a small increase of $\mathrm{NO}_{3}-\mathrm{N}$ because of insufficient available organic carbon. An aerobic/anoxic time of $2 \mathrm{~h} / \mathrm{h}$ instead of $\mathrm{h} / \mathrm{h}$ results in lower $\mathrm{NH}_{4}-\mathrm{N}$ but higher $\mathrm{NO}_{3}-\mathrm{N}$ because of less bypass flow and longer aeration periods. Decreasing the dosing time of acetic acid without changing the total anoxic period results in decrease of $\mathrm{NO}_{3}-\mathrm{N}$ and TN.

Increasing the SRT, aeration periods and dosage of acetic acid on the anoxic period results in $\mathrm{NH}_{4}-\mathrm{N}$ and TN below $4 \mathrm{mg} \mathrm{N} / \mathrm{L}$ and $10 \mathrm{mg} \mathrm{N} / \mathrm{L}$, respectively.

\section{REFERENCES}

1. Abusam, A., Keesman, K.J., van Straten, G., Spanjers, H. and Meinema, K. 2001. Sensitivity analysis in oxidation ditch modelling: the effect of variations in stoichiometric, kinetic and operating parameters on the performance indices, J. Chem. Technol. Biotechnol, 76: $430-438$

2. Copp, J.B. 2000. Defining a simulation benchmark for control strategies, Water21, 1(2): 44-49

3. Henze, M., Grady, C.P.L.Jr., Gujer, W., Marais, G.v.R. and Matsuo, T. 1986. [IAWQ Task Group on Mathematical Modelling for Design and Operation of Biological Wastewater Treatment] Activated sludge model No. 1, Scientific and Technical Reports No. 1, IAWQ

4. Horner, R.M.W., Jarvis, R.J. and Mackie, R.I. 1986. Deep bed filtration: a new look at the basic equations. Wat. Res., 20(2): 215-220

5. Hydromantis, 1999. Technical Reference, Version 4.0, Hydromantis, Hamilton 
6. Ponds, M.N., Spanjers, H. and Jeppsson, U. 1999. Towards a benchmark for evaluating control strategies in wastewater treatment plants by simulations, Escape 9 (European symposium on computer aided process engineering-9), Budapest

7. Roeleveld, P.J. and Loosdrecht, M.C.M.van 2002. Experience with guidelines for wastewater characterization in the Netherlands, Wat. Sci. Tech., 45(6): $77-87$.
8. Vanrolleghem, P.A., Jeppsson, U., Carstensen, J., Carlsson, B., and Olsson, G. 1996. Integration of WWT plant design and operation-A systematic approach using cost functions, Wat. Sci. Tech., 34(3-4): 159171 